\title{
A GYTOTAXONOMIC STUDY OF VIOLA IN THE NETHERLANDS
}

\author{
T. W. J. GADELLA \\ (Botanical Museum and Herbarium, Utrecht) \\ (received November 19th, 1962)
}

\begin{abstract}
1. The chromosome numbers of 10 species of the genus Viola in the Netherlands were determined.

2. Viola riviniana has various chromosome numbers: $2 n=35,40,45,46,47$ (most often $2 n=40$ ).

3. It was not possible to find a correlation between the external morphology and the various chromosome numbers in $V$. riviniana.

4. Despite the variability of $V$. riviniana it proved impossible to divide the Dutch material into subspecies.

5 . Some differential characters of $V$. riviniana and $V$. reichenbachiana are described.

6. $V$. canina is not variable in cytological respect in the Netherlands.

7. V. calaminaria is not related to $V$. lutea but to the $V$. tricolor complex.
\end{abstract}

\section{INTRODUGTION}

Up to the present numerous investigations into the cytology of the genus Viola have been carried out. The chromosome numbers of many species are now known; moreover, as much experimental crossing has been done, a combination of morphological, cytological and genetical data is available.

In some cases, however, only a few plants of a species were examined. Therefore, the available information pertained only to a part of the entire area of the species. In the Netherlands none of the species was cytologically examined.

Clausen $(1931, \mathrm{~b})$, studying the cytology of Viola canina in Denmark, obtained results quite different from those of BRUUN (1932) in Sweden, Fothergill (1944) in England and Schöfer (1954) and SchmidT (1961) in Germany. The Dutch material was not examined.

Viola riviniana was studied in England by VAlentine (1941, 1949, $1950,1956,1958)$ and in South Germany by SchöfER (1954). In England five different chromosome numbers were found: $2 \mathrm{n}=35$, $40,45,46$, and 47 respectively (most often 40), whereas in South Germany only the number $2 n=40$ was obtained. The British plants produced abundant seed and apparently had not originated through hybridization. In certain plants from British populations 5, 6 or 7 small "supernumerary" or "B" chromosomes were present. According to Schmid (1961) this has not yet been found in continental plants. Valentine described extensively the British plants of Viola riviniana and Viola reichenbachiana and their artificially produced hybrid. Schöfer studied South German plants of putative hybrid origin, but gave only inadequate descriptions. Whereas the hybrids produced artificially in Britain all have the number $2 \mathrm{n}=30$, two types of hybrids were 
found to occur in South Germany; one, accounting for $90 \%$ of the total, had $2 n=40$, the remaining $10 \%$ had $2 n=30$. Another point of difference is that the hybrids from Germany proved to be fertile, whereas the British ones were virtually completely sterile.

According to VAlentine (1941), the British population of $V$. riviniana consists of two morphologically distinct subspecies, a type of woods (Viola riviniana Rchb. subspec. nemorosa N.W. et $\mathbf{M}$. emend. Valentine) and a type of open grassland [ $V$. riviniana $R \mathrm{chb}$. subspec. minor (Murbeck) Valentine]. There are, however, intermediate types from intermediate habitats.

As neither the cytology nor the morphological variability of $V$. riviniana in the Netherlands had been investigated, it seemed worthwhile to undertake a study of these subjects.

Another interesting problem in the Dutch violets is the chromosome number of Viola calaminaria Lej. This had never been satisfactorily established, despite several attempts. It is true that GrIEsINGER (1937) was able to determine it in the blue zinc-violets of Blankenrode, Westphalia, but morphologically these plants are not identical with those from the South of the Netherlands.

On various grounds Heimans (1936) suggested that our yellowflowered zinc-violets are morphologically closer to the Viola tricolor complex $(2 n=26)$ than to $V$. lutea $(2 n=48)$, with which they are usually classified in floras. This conclusion is, however, subject to dispute, as Clausen $(1931, c)$ counted $2 \mathrm{n}=\mathrm{ca} .48$ for $V$. lutea Huds. var. multicaulis Koch ( $=V$. calaminaria Lej.). Hermans (1960) found a higher number, $2 \mathrm{n}=$ prob. 52 , but the exact number could not be established. One of the objectives of the present study was to obtain an exact count of $V$. calaminaria and to compare the species morphologically with $V$. tricolor. Finally, the chromosome numbers of all Dutch species (exept $V$. stagnina) were determined, in order to obtain a more complete picture of the cytogeography of these species.

\section{Material AND METhods}

Living plants were collected in the Netherlands and some adjacent regions. All plants were cultivated during 4 years in the Cantonspark at Baarn, the Botanical Garden of the State University of Utrecht. Only living plants were studied morphologically. Herbarium material of most of the plants was deposited in the Utrecht Herbarium.

The chromosome counts were made from mitoses in root-tips. These were fixed in Karpechenko, embedded in paraffin, sectioned at $15 \mu$, and stained according to the haematoxylin or the gentian violet-iodine method. The chromosome portraits were drawn with the aid of an Abbé Camera Lucida.

\section{Results}

Table 1 gives a summary of the author's chromosome counts, with indication of the origin of the material, the number of plants, and 


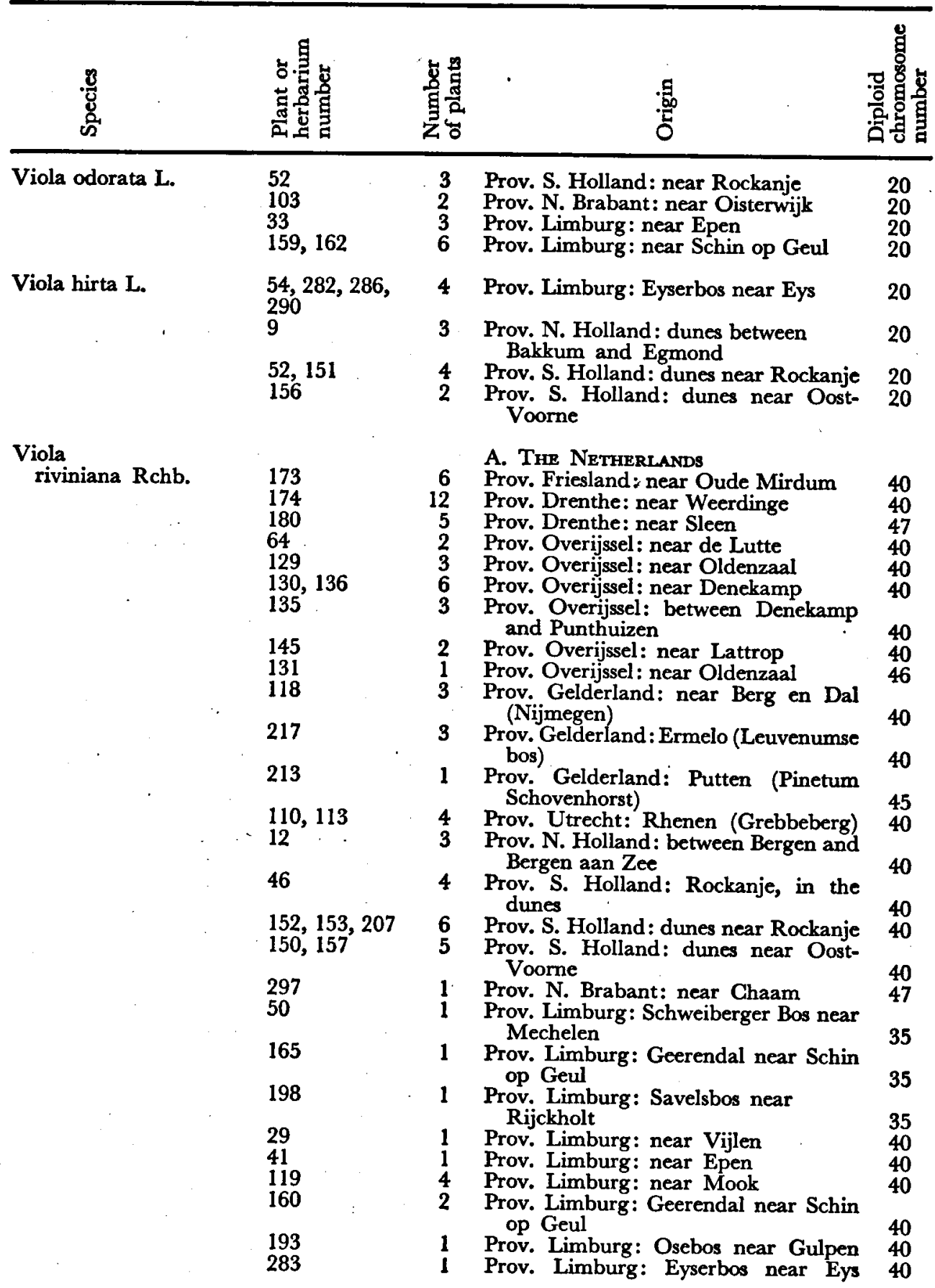




\begin{tabular}{|c|c|c|c|c|}
\hline 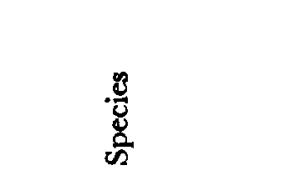 & 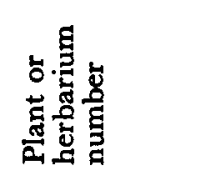 & 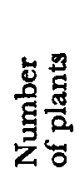 & 恖 & 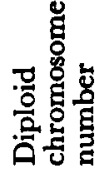 \\
\hline \multirow{16}{*}{$\begin{array}{l}\text { Viola } \\
\text { reichenbachiana } \\
\text { Jord. ex Bor. }\end{array}$} & $\begin{array}{l}317,354,373, \\
374,377,378, \\
379,381,382, \\
384,385,387, \\
390,391,397 \\
39\end{array}$ & 16 & $\begin{array}{l}\text { Prov. Limburg: on slopes in the } \\
\text { "Schweiberger bos" near Mechelen }\end{array}$ & 40 \\
\hline & 17 & 3 & $\begin{array}{l}\text { Epen } \\
\text { Prov. Limburg: Ravensbos near } \\
\text { Valkenburg } \\
\text { B. W. GERMANY }\end{array}$ & $\begin{array}{l}45 \\
46\end{array}$ \\
\hline & $\begin{array}{l}235 \\
243\end{array}$ & 1 & $\begin{array}{l}\text { Lower Saxony: Bentheim } \\
\text { Lower Saxony: Bentheim }\end{array}$ & $\begin{array}{l}40 \\
47\end{array}$ \\
\hline & $\begin{array}{l}201,202,203 \\
204,284,285\end{array}$ & 7 & $\begin{array}{l}\text { Prov. Liège: Ruine Reinardstein near } \\
\quad \text { Robertville }\end{array}$ & 40 \\
\hline & $287,288,289$ & 3 & $\begin{array}{l}\text { Prov. Luxembourg: Between Marche en } \\
\text { Vamennes and La Roche en Ardennes }\end{array}$ & 40 \\
\hline & 101 & 3 & Prov. Luxembourg: near Bérismenille & 40 \\
\hline & 4 & 1 & $\begin{array}{l}\text { A. The NetherLands } \\
\text { Prov. Overijssel: Austieberg near Dene- }\end{array}$ & \\
\hline & $5,58,63$ & 4 & Prov. Overijssel: Lomanskamp near & \\
\hline & 37 & 2 & Prov. Limburg: Onderste Bos near & 0 \\
\hline & $191,192,194$ & 5 & Prov. Limburg: Osebos near Gulpen & 20 \\
\hline & & 1 & $\begin{array}{l}\text { Prov. Limburg: Savelsbos near } \\
\text { Rijckholt }\end{array}$ & 20 \\
\hline & $\begin{array}{l}199,200 \\
355,372,375, \\
376,380,383, \\
386,388,389, \\
392,393,394, \\
395,396,397\end{array}$ & $\begin{array}{r}2 \\
15\end{array}$ & $\begin{array}{l}\text { Prov. Limburg: Eyserbos near Eys } \\
\text { Prov. Limburg: on slopes in the } \\
\text { Schweiberger Bos near Mechelen }\end{array}$ & 20 \\
\hline & 190 & 3 & $\begin{array}{l}\text { B. BeLgrum } \\
\text { Prov. Limburg: near Lanaken }\end{array}$ & 20 \\
\hline & $229,236,237$ & 6 & Lower Saxony: near Bentheim & 20 \\
\hline & $240,241,244$ & 3 & Lower Saxony: Burg Steinfurt near & 20 \\
\hline & 243,246 & 2 & Lower Saxony: $3 \mathrm{~km}$ North of Bentheim & 20 \\
\hline \multirow{2}{*}{$\begin{array}{l}\text { Viola rupestris } \\
\text { F. Schmidt } \\
\text { var. arenaria (D.C.) } \\
\text { W. Beck. }\end{array}$} & 205 & 3 & $\begin{array}{l}\text { Prov. N. Holland: Bergen aan Zee } \\
\text { (collected by Ir. H. Doing Craft) }\end{array}$ & 20 \\
\hline & 293 & 1 & $\begin{array}{l}\text { Prov. S. Holland: Oost-Voorne } \\
\text { (collected by C. Sipkes) }\end{array}$ & 20 \\
\hline Viola canina $\mathbf{L}$. & $\begin{array}{l}208,209,210 \\
211,212\end{array}$ & 5 & $\begin{array}{l}\text { Prov. Friesland: Isle of } \\
\text { Schiermonnikoog }\end{array}$ & 40 \\
\hline
\end{tabular}


TABLE 1 (Continued)

\begin{tabular}{|c|c|c|c|c|}
\hline 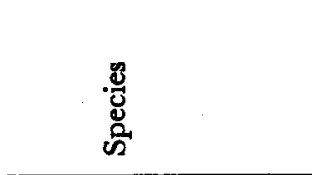 & 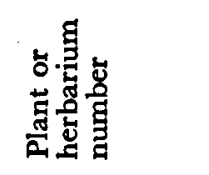 & 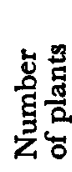 & $\frac{5}{60}$ & 总 \\
\hline & 175 & 2 & Prov. Drenthe: Valtherzand near & 4 \\
\hline & $\begin{array}{l}249 \\
96 \\
148 \\
179 \\
1 \\
84,85,87\end{array}$ & $\begin{array}{l}1 \\
3 \\
1 \\
3 \\
3 \\
9\end{array}$ & $\begin{array}{l}\text { Prov. Drenthe: near Oosterhessele } \\
\text { Prov. Overijssel: near Marienberg } \\
\text { Prov. Overijssel: near de Lutte } \\
\text { Prov. Overijssel: near Gramsbergen } \\
\text { Prov. Utrecht: near Soestdijk } \\
\text { Prov. Utrecht: between Maarn and }\end{array}$ & $\begin{array}{l}40 \\
40 \\
40 \\
40 \\
40\end{array}$ \\
\hline & & 4 & Prov. N. Holland: dunes of Texel & \\
\hline & 8 & 1 & Prov. N. Holland: dunes of Texel & \\
\hline & 181 & 1 & Prov. N. Holland: dunes of Texel & \\
\hline & 70,73 & 6 & $\begin{array}{l}\text { (near den Hoorn) } \\
\text { Prov. N. Holland: dunes near Bergen }\end{array}$ & 40 \\
\hline & $\begin{array}{l}81 \\
214 \\
271,262,269,\end{array}$ & $\begin{array}{l}3 \\
3 \\
4\end{array}$ & $\begin{array}{l}\text { aan Zee } \\
\text { Prov. N. Holland: near St. Maartenszee } \\
\text { Prov. S. Holland: Goudriaen } \\
\text { Prov. S. Holland: near Oost-Voorne }\end{array}$ & $\begin{array}{l}40 \\
40 \\
40 \\
40\end{array}$ \\
\hline & $\begin{array}{l}265 \\
108,109\end{array}$ & $\begin{array}{l}1 \\
6\end{array}$ & $\begin{array}{l}\text { Prov. S. Holland: near Rockanje } \\
\text { Prov. N. Brabant: near Rosmalen }\end{array}$ & $\begin{array}{l}40 \\
40\end{array}$ \\
\hline Viola palustris $\mathbf{L}$. & $\begin{array}{l}132 \\
248 \\
83 \\
100\end{array}$ & $\begin{array}{l}3 \\
1 \\
2 \\
3\end{array}$ & $\begin{array}{l}\text { Prov. Overijssel : near Denekamp } \\
\text { Prov. Gelderland: near Ermelo } \\
\text { Prov. Utrecht: near Maarn } \\
\text { Belgium. - Prov. Luxembourg: near } \\
\text { Mochamps. }\end{array}$ & $\begin{array}{l}48 \\
48 \\
48 \\
48\end{array}$ \\
\hline $\begin{array}{l}\text { Viola tricolor } \mathbf{L} \text {. } \\
\text { a) subspec. tricolor }\end{array}$ & $\begin{array}{l}172 \\
177 \\
92,99 \\
116\end{array}$ & $\begin{array}{r}8 \\
1 \\
3 \\
10\end{array}$ & $\begin{array}{l}\text { Prov. Friesland: near Oude Mirdum } \\
\text { Prov. Overijssel: near Marienberg } \\
\text { Prov. Overijssel: near Ommen } \\
\text { Prov. N. Holland: between Hollandse } \\
\text { Rading and Hilversum }\end{array}$ & $\begin{array}{l}26 \\
26 \\
26 \\
26\end{array}$ \\
\hline \multirow[t]{2}{*}{$\begin{array}{l}\text { b) subspec. curtisii } \\
\text { (Forst.) Syme }\end{array}$} & $\begin{array}{l}67,71 \\
10\end{array}$ & $\begin{array}{l}2 \\
2\end{array}$ & $\begin{array}{l}\text { Prov. N. Holland: near Bergen aan Zee } \\
\text { Prov. N. Holland: near Egmond a/d } \\
\text { Hoef }\end{array}$ & 26 \\
\hline & $\begin{array}{l}48 \\
43 \\
128\end{array}$ & $\begin{array}{l}2 \\
2 \\
9\end{array}$ & $\begin{array}{l}\text { Prov. S. Holland: near Rockanje } \\
\text { Prov. S. Holland: near Oost-Voorne } \\
\text { Prov. S. Holland: near Ouddorp }\end{array}$ & $\begin{array}{l}26 \\
26 \\
26\end{array}$ \\
\hline Viola arvensis Murr. & $\begin{array}{l}176 \\
93 \\
133 \\
114 \\
216 \\
102 \\
186 \\
105\end{array}$ & $\begin{array}{r}2 \\
3 \\
3 \\
3 \\
10 \\
2 \\
2 \\
2\end{array}$ & $\begin{array}{l}\text { Prov. Drenthe: near Emmen } \\
\text { Prov. Overijssel: near Ommen } \\
\text { Prov. Overijssel: near Denekamp } \\
\text { Prov. Utrecht: near Utrecht } \\
\text { Prov. N. Holland : near Hilversum } \\
\text { Prov. N. Brabant: near Oisterwijk } \\
\text { Prov. N. Brabant: near Valkenswaard } \\
\text { Prov. N. Brabant: near Rosmalen }\end{array}$ & $\begin{array}{l}34 \\
34 \\
34 \\
34 \\
34 \\
34 \\
34 \\
34\end{array}$ \\
\hline Viola calaminaria Lej. & 168 & 6 & Belgium. - Prov. Liège: La Calamine & 52 \\
\hline
\end{tabular}



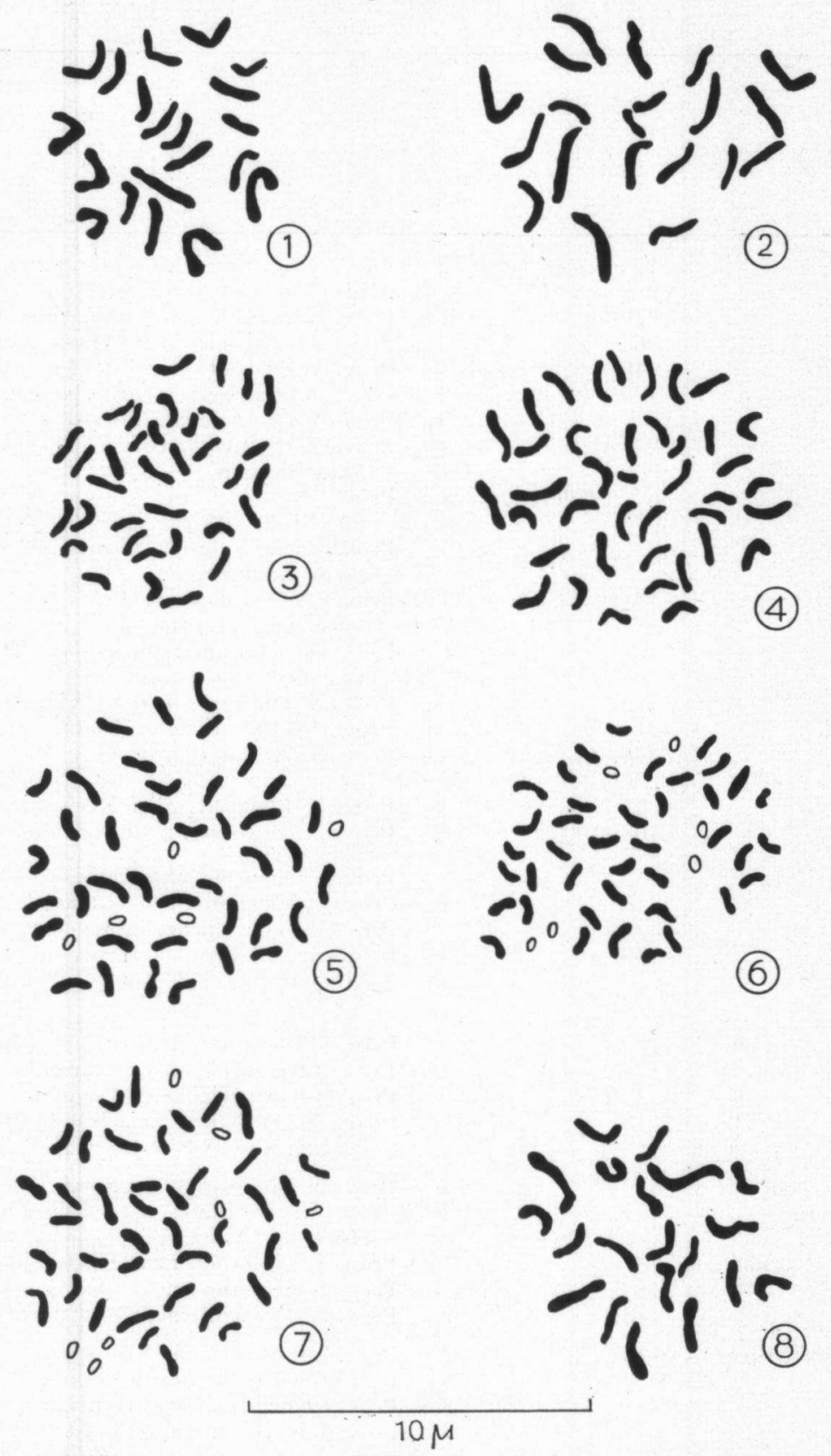

Fig. 1A. 1. Viola odorata L. $2 \mathrm{n}=20$. Orig.: Epen; 2. Viola hirta L. $2 \mathrm{n}=20$. Orig.: Eys; 3 . Viola riviniana $R$ chb. $2 \mathrm{n}=35$. Orig.: Mechelen; 4 . Viola riviniana Rchb. $2 n=40$. Orig.: $R$ henen; 5 . Viola riviniana $R$ chb. $2 n=45$. Orig.: Putten; 6. Viola riviniana Rchb. $2 n=46$. Orig.: Valkenburg; 7. Viola riviniana Rchb. $2 n=47$. Orig.: Sleen; 8. Viola reichenbachiana Jord. ex Bor. $2 n=20$. Orig.: Epen. 

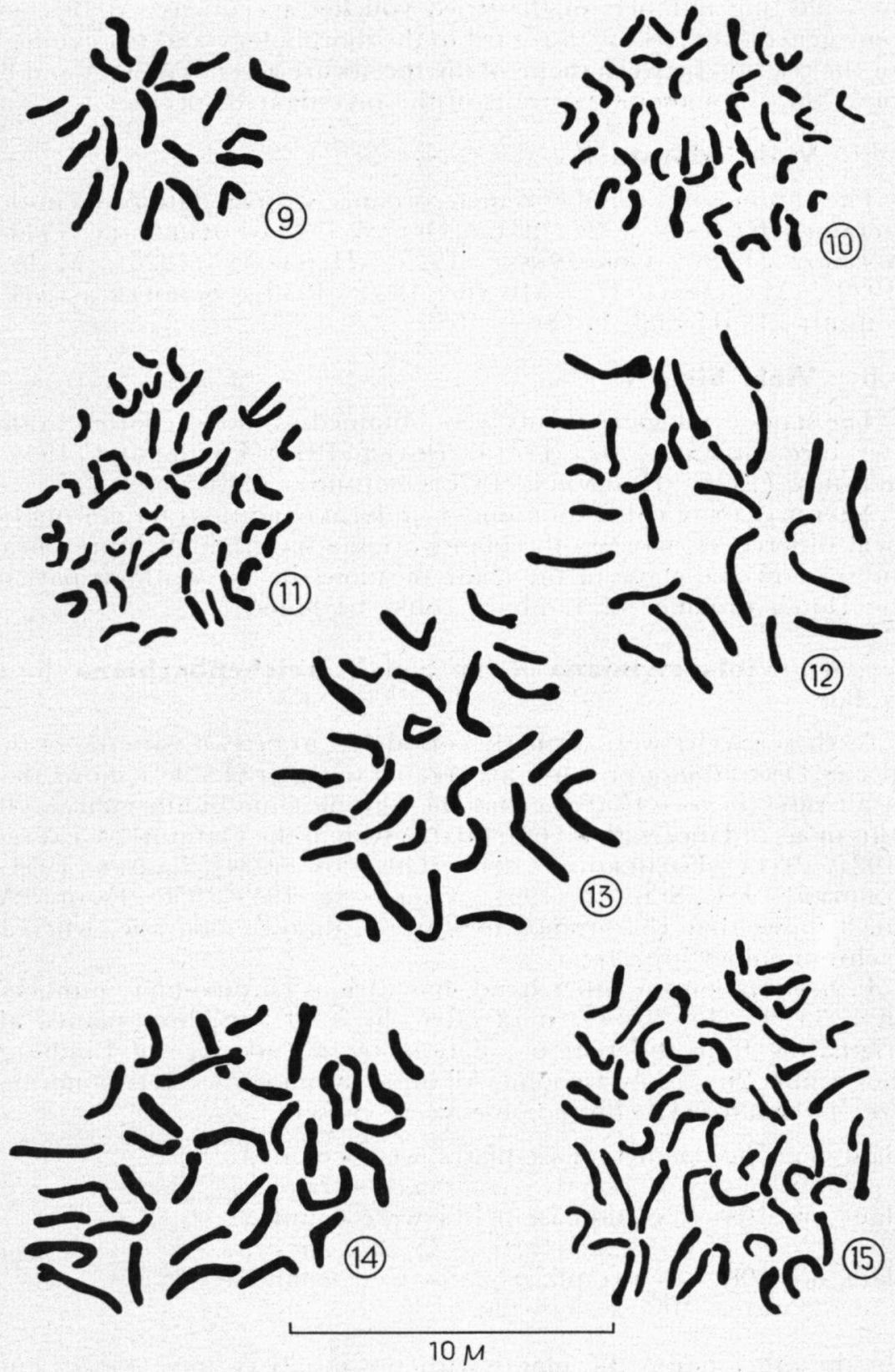

(13)

Fig. 1B. 9. Viola rupestris F. W. Schmidt var. arenaria (D.C.) W. Beckr. $2 \mathrm{n}=20$. Orig.: Rockanje; 10. Viola canina L. $2 \mathrm{n}=40$. Orig.: Gramsbergen; 11. Viola palustris L. $2 \mathrm{n}=48$. Orig.: Maarn; 12. Viola tricolor $\mathrm{L}$. subspec. curtisii (Forst.) Syme $2 n=26$. Orig.: Oost-Voorne; 13. Viola tricolor L. subspec. tricolor $2 n=26$. Orig.: Hollandse Rading; 14. Viola arvensis Murr. $2 n=34$. Orig.: Emmen 15. Viola calaminaria Lej: $2 n=52$. Orig.: la Calamine. 
the collecting numbers of the dried voucher specimens. At the end some general remarks with regard to the morphology and the cytology (or the relation between them) of the species are given. Fig. 1 (A and B) shows the chromosome portraits of the investigated species.

\section{a) Viola odorata L.}

The chromosome number is in accordance with all data given in the literature: Clausen (1927, 1931a), Delay (1948), Fothergill (1944), Gershoy (1928), Gorczynski (1929), Heilborn (1926), MAdGe (1929), Manch (1937), Mryajt (1929, 1930), Schöfer (1954), SchMiDT (1961) and THÉRON (1939).

\section{b) Viola hirta L.}

The same cytological results were obtained as those reported in the literature: Clausen (1927, 1931a), Delay (1948), Fothergill (1944), Gershoy (1934), Heilborn (1926), Schmidt (1961).

After 4 years of cultivation under uniform conditions no morphological differences between the plants originating from the dunes near the sea-cost and those of the chalk-meadows in the southern part of the Dutch province of Limburg could be found.

c, d) Viola riviniana Rchb. and V. reichenbachiana Jord. ex Bor.

As these species were formerly considered to be two varieties of the species Viola silvatica Fr., they are treated together. Table 1 shows that in all cases $V$. reichenbachiana has the chromosome number $2 n=20$. This in accordance with all other data given in the literature: Cladusen (1927, 1931a), Fothergill (1944), Gershoy (1934), LARSEN (1954), Schöfer (1954), Schmidt (1961), Valentine (1949, 1950). Figure 1A, no. 8 shows that 18 chromosomes are of almost equal size, whereas 2 chromosomes are larger.

$V$. riviniana, on the other hand, has various chromosome numbers: $2 n=35,40,45,46,47$ (most often $2 n=40$ ). In three plants, all originating from different populations in the province of Limburg, the number $2 n=35$ was found. All these chromosomes were of normal size; no small or B-chromosomes were present.

plant no. 50: 5 metaphase-plates were counted:

$4 \times$ exactly $2 n=35,1 \times 2 n=$ ca. 33

plant no. 165: 7 metaphase-plates were counted:

$6 \times$ exactly $2 \mathrm{n}=35,1 \times 2 \mathrm{n}=37$.

plant no. 198: 12 metaphase-plates were counted:

$10 \times$ exactly $2 \mathrm{n}=35,2 \times 2 \mathrm{n}=34$.

On the other hand, the plants with the numbers $2 n=45,46$ and 47 showed 5, 6 or 7 small supernumerary or B-chromosomes. All plants showed quite normal pollengrains.

Notwithstanding the fact that there are many differences between these species, they resemble each other to a certain extent in general 


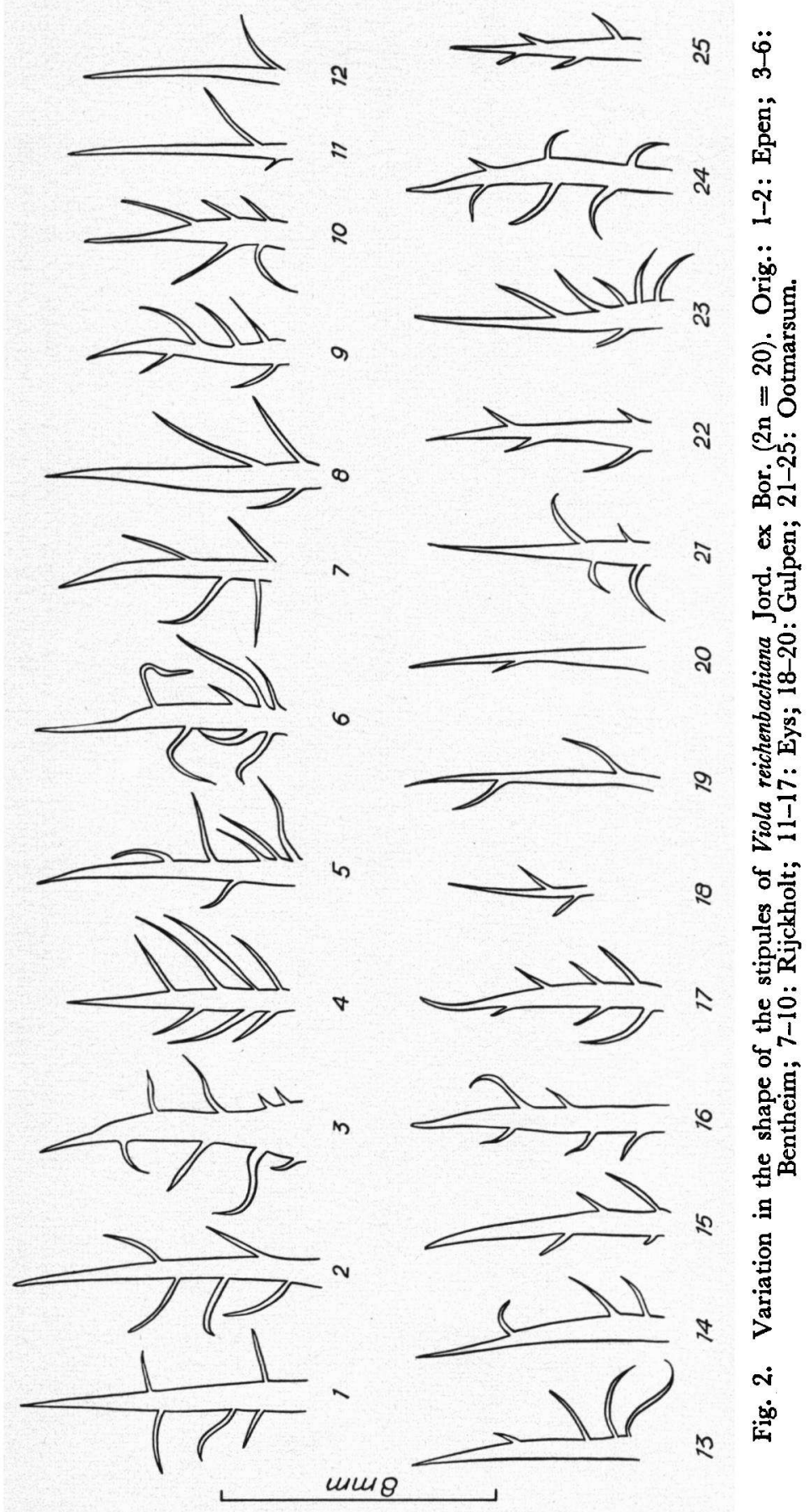


T. W. J. GADELLA

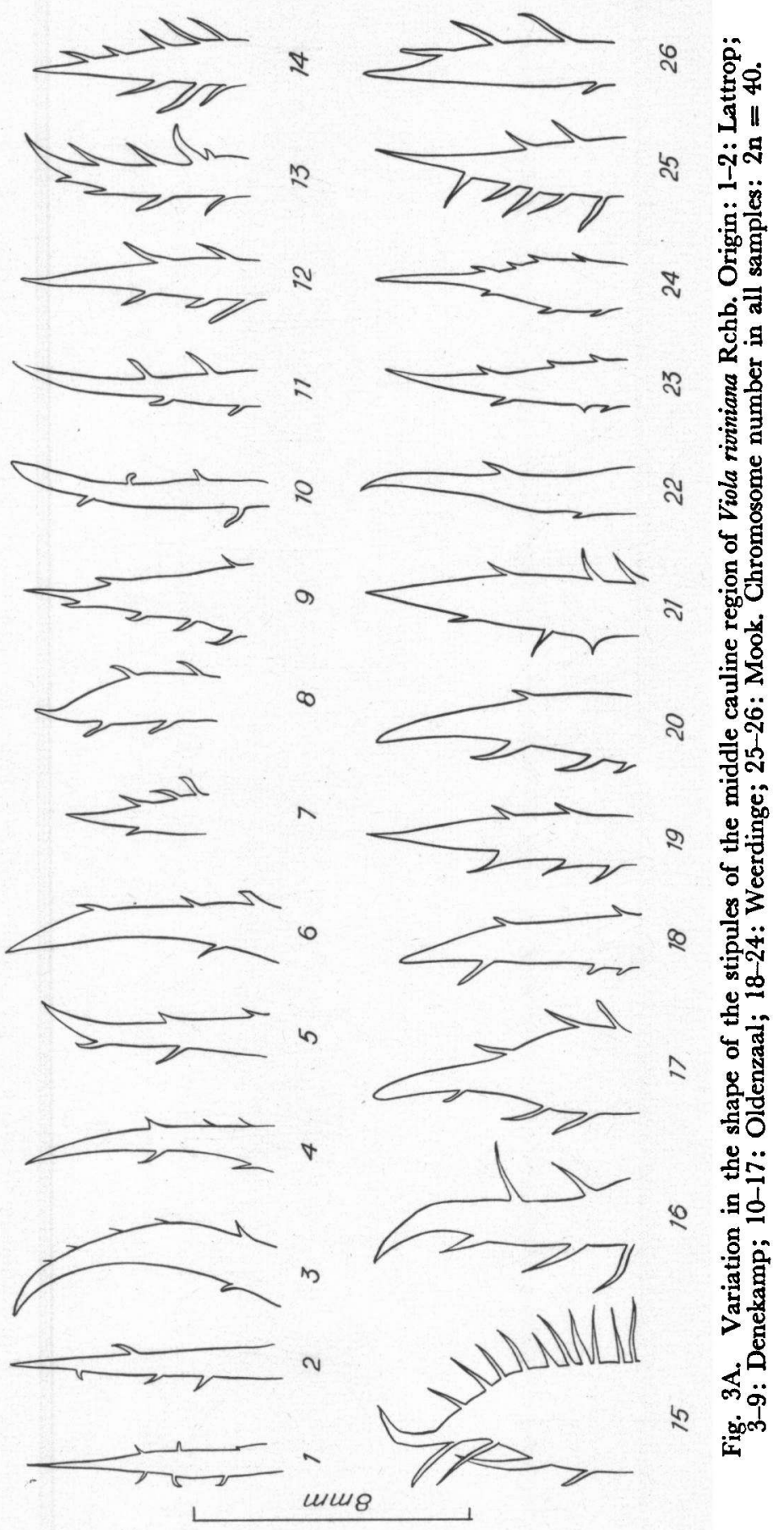




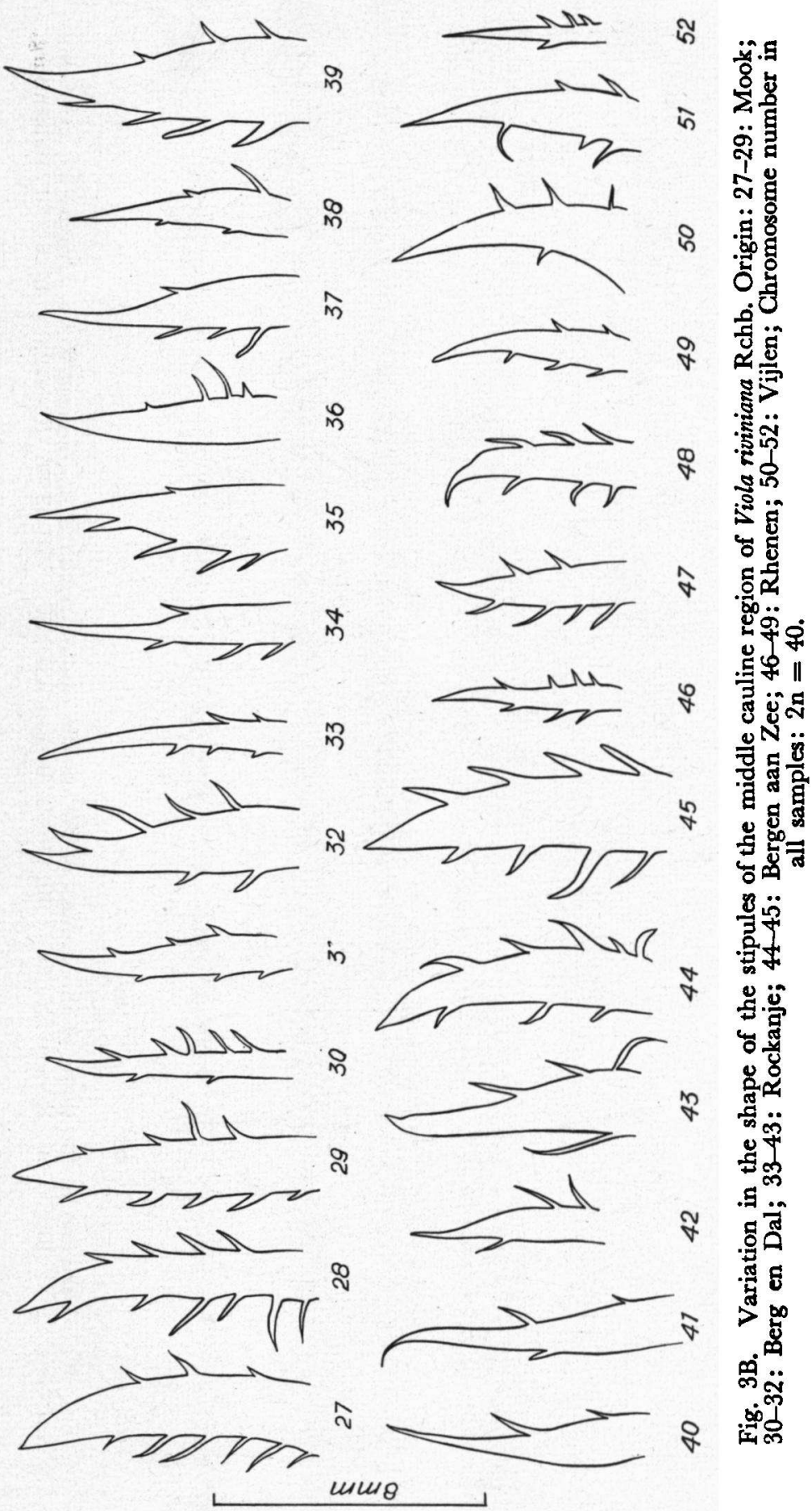




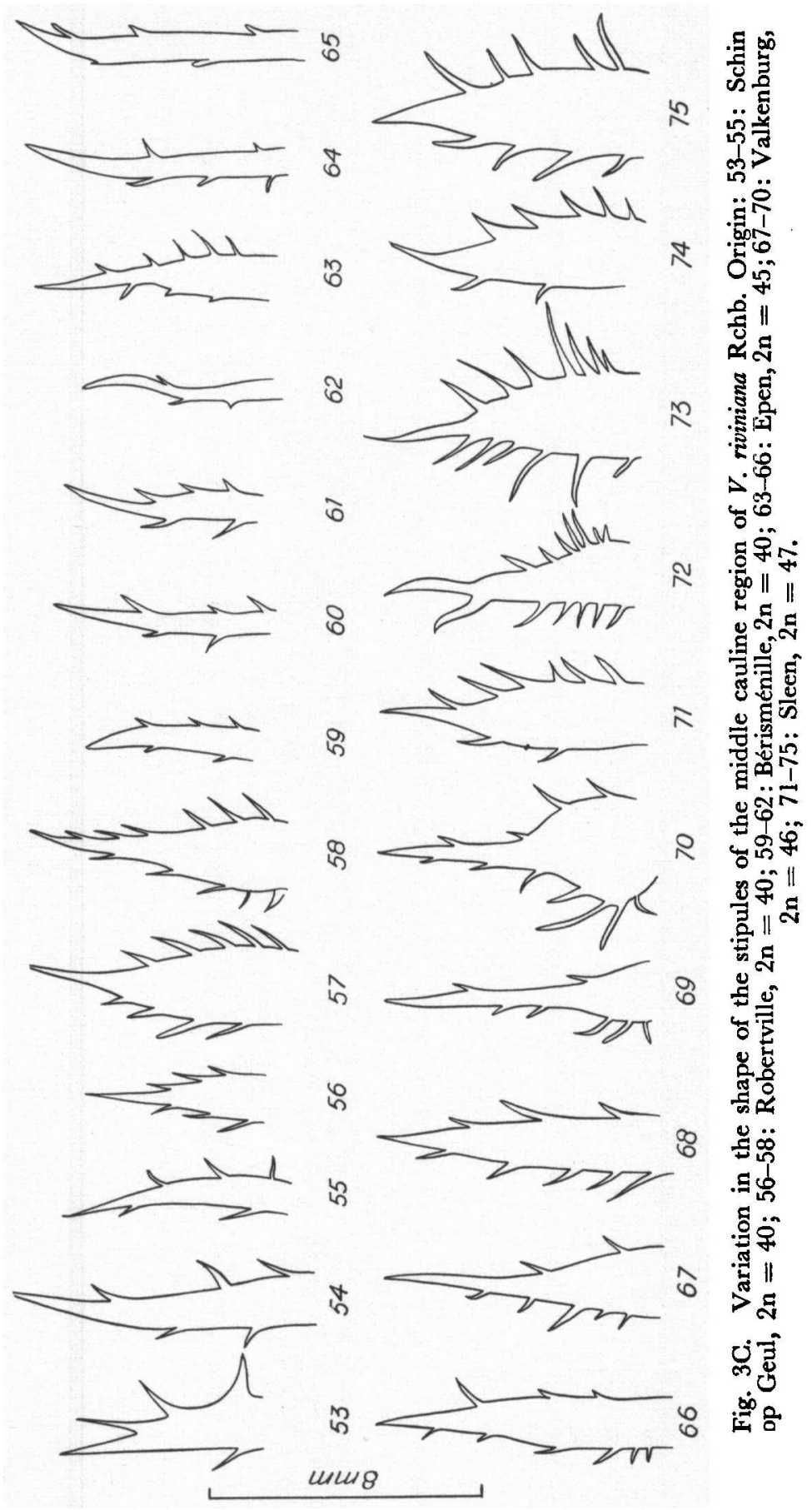


appearance. As it is almost impossible to study some flower characters, among which some of diagnostic value, in dried material, the morphological studies are only based on living plants. The characters described below remained constant under uniform garden conditions.

The vegetative characters of both species agree in many respects. The leaves of $V$. reichenbachiana are often smaller than those of $V$. riviniana, but there is a considerable overlap. The same holds true for the hairiness of the leaves. The stipules are manifestly different. Fig. 2 shows the variation in the shape of the stipules of $V$. reichenbachiana, and Fig. 3 (A, B, C) of V. riviniana. Stipules of plants originating from different habitats were examined. In every case the most typical examples were drawn. The stipules of the uppermost leaves of $V$. riviniana are often entire, but those of the middle ones are fringed. In $V$. riviniana the fringes are short; the width of a stipule at the place of insertion of a fringe is never smaller than the length of that fringe. In $V$. reichenbachiana the fringes are longer. The number of fringes per stipule fluctuates in both species. In $V$. riviniana the stipules are generally, but not always, broader than in $V$. reichenbachiana. The plants originating from Sleen (no. 180), $2 \mathrm{n}=47$, have broad stipules. This is, however not typical for all plants with a high chromosome number, for there are also plants with the number $2 \mathrm{n}=40$ (Fig. 3A, no. 15) with broad stipules. As was pointed out by VAlentine (1949), the plants with supernumerary chromosomes have adventitious shoots. This phenomenon could only be observed in the plants from Sleen (plant no. 180). It was, however, not checked in all plants.

The flowers of the two species are clearly different. Figure 4 shows the differences between the lower, spurred, petals. All plants with the number $2 n=20$ have small petals, the lower one provided with a slender, pointed, dark purple spur, whereas the plants with the number $2 \mathrm{n}=35,40,45,46,47$ have broad petals and stouter, furrowed spurs of different colour (white, light to dark purple, and partly white, partly purple.) The venation of the lower petal agrees with that of the British plants described by Valentine. The purple veins of $V$. riviniana branch out and fill the distal part of the petal, whereas those of $V$. reichenbachiana are fewer in number and are restricted to the central part of the petal. The veins of $V$. riviniana remain distinctly seperate, those of $V$. reichenbachiana become diffuse in the usually dark purple-spotted centre of the lower petal. The colour of the spur of $V$. riviniana is not correlated with the occurrence of supernumerary chromosomes: the spur is white in plant, plant no. 131 $(2 n=46)$, plant no. $213(2 n=45)$ and purple in plant no. 39 $(2 n=45)$, plant no. $17(2 n=46)$, plant no. $243(2 n=47)$ and plant no. $180(2 \mathrm{n}=47)$.

The diameter of the pollengrains is somewhat larger in $V$. riviniana than in $V$. reichenbachiana (table 2):

The number of seeds per fruit is higher in $V$. riviniana than in $V$. reichenbachiana, as shows Fig. 5. Fruits from cleistogamous flowers were collected at random in July in different populations, viz. 86 fruits of $V$. reichenbachiana and 105 of $V$. riviniana. 

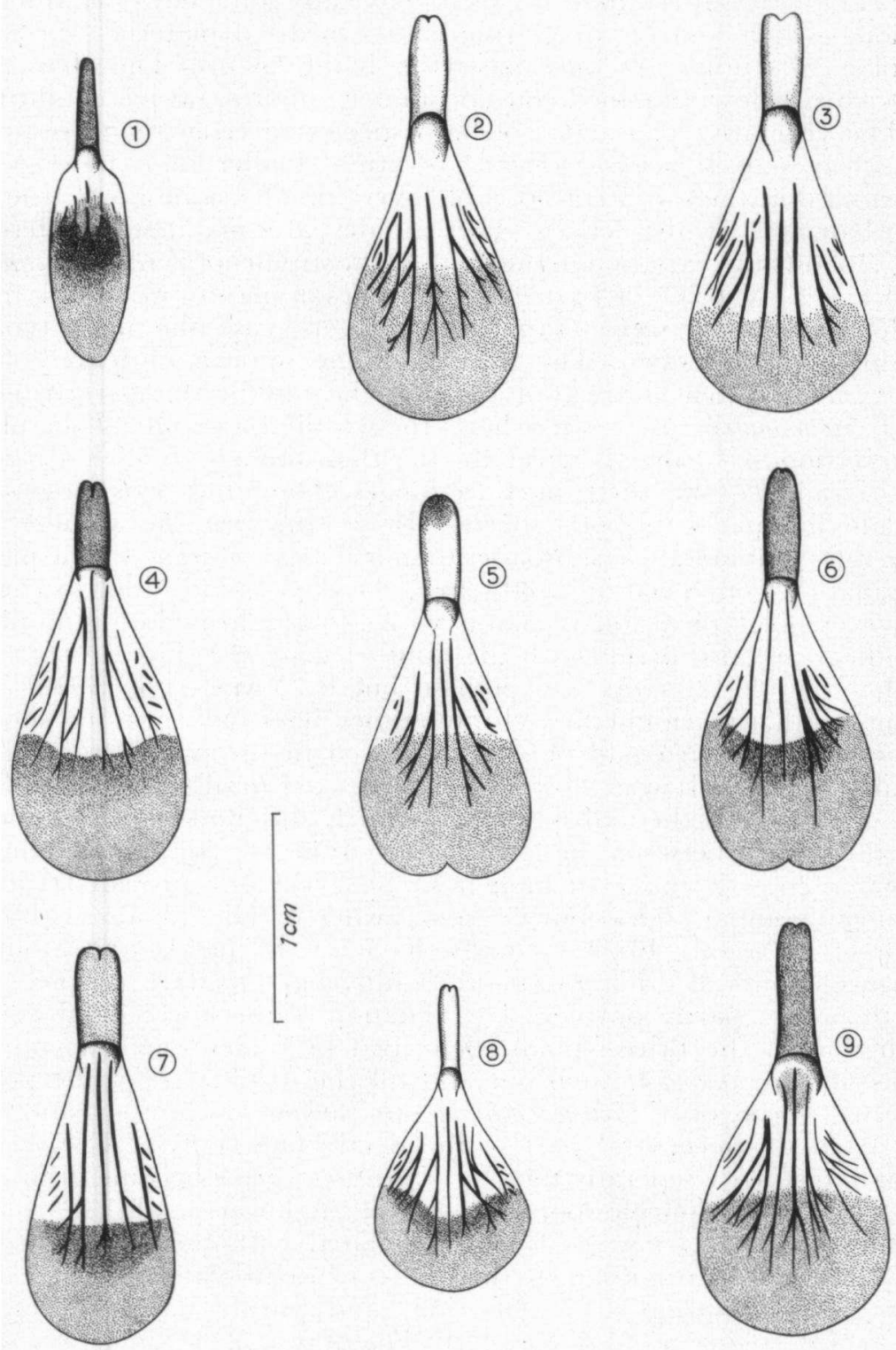

Fig. 4. Lower petal and spur of Viola reichenbachiana Jord. ex Bor. (1) and Viola riviniana Rchb. (2-9). 1. $2 n=20$. Orig.: Ootmarsum. Spur dark purple; $2.2 n=40$. Orig.: Epen. Spur white; 3. $2 n=40$. Orig.: Lattrop. Spur white; 4. $2 n=40$. Orig.: Oude Mirdum. Spur purple; 5. $2 n=40$. Orig.: Rhenen. Spur white-purple; 6. $2 n=40$. Orig.: Schin op Geul. Spur purple; $7.2 n=45$. Orig.: Epen. Spur light purple; 8 . $2 n=46$. Orig.: Oldenzaal. Spur white; 9 . $2 n=47$. Orig.: Sleen. Spur purple. 
TABLE 2

\begin{tabular}{|c|c|c|c|c|c|c|c|c|}
\hline Species and & $2 n$ & $20-24 \mu$ & $24-28 \mu$ & $28-32 \mu$ & $32-36 \mu$ & $36-40 \mu$ & $40-44 \mu$ & $44-46 \mu$ \\
\hline $\begin{array}{l}\text { Oorrgin } \\
\text { V. reichen- } \\
\text { bachiana } \\
\text { (Mechelen) }\end{array}$ & 20 & $2 \%$ & $48 \%$ & $44 \%$ & $2 \%$ & - & - & - \\
\hline $\begin{array}{l}\text { V. reichen- } \\
\text { bachiana } \\
\text { (Ootmarsum) }\end{array}$ & 20 & $2 \%$ & $39 \%$ & $59 \%$ & - & - & - & - \\
\hline $\begin{array}{l}\text { V. reichen- } \\
\text { bachiana } \\
\text { (Bentheim) }\end{array}$ & 20 & - & $30 \%$ & $70 \%$ & - & - & - & - \\
\hline $\begin{array}{l}\text { Viviniana } \\
\text { (Rhenen) }\end{array}$ & 40 & - & $1 \%$ & $40 \%$ & $59 \%$ & - & 一 & - \\
\hline $\begin{array}{l}\text { Viviniana } \\
\text { (Weerdinge) }\end{array}$ & 40 & - & $3 \%$ & $57 \%$ & $35 \%$ & $3 \%$ & - & - \\
\hline $\begin{array}{l}\text { V. riviniana } \\
\text { (Rockanje) }\end{array}$ & 40 & - & - & $78 \%$ & $22 \%$ & - & 一 & - \\
\hline $\begin{array}{c}\text { V. riviniana } \\
\text { (Lattrop) }\end{array}$ & 40 & - & $8 \%$ & $48 \%$ & $36 \%$ & $6 \%$ & - & - \\
\hline $\begin{array}{l}\text { V. riviniana } \\
\text { (Valkenburg) }\end{array}$ & 46 & - & - & $36 \%$ & $38 \%$ & $26 \%$ & - & - \\
\hline $\begin{array}{l}\text { V. riviniana } \\
\text { (Sleen) }\end{array}$ & 47 & - & - & $18 \%$ & $48 \%$ & $28 \%$ & $4 \%$ & $2 \%$ \\
\hline
\end{tabular}

The relation between the number of chromosomes and the diameter of the pollengrains of 9 populations of $V$. riviniana $R$ chb. and $V$. reichenbachiana Jord. ex Bor. (In each sample 100 pollengrains were measured).

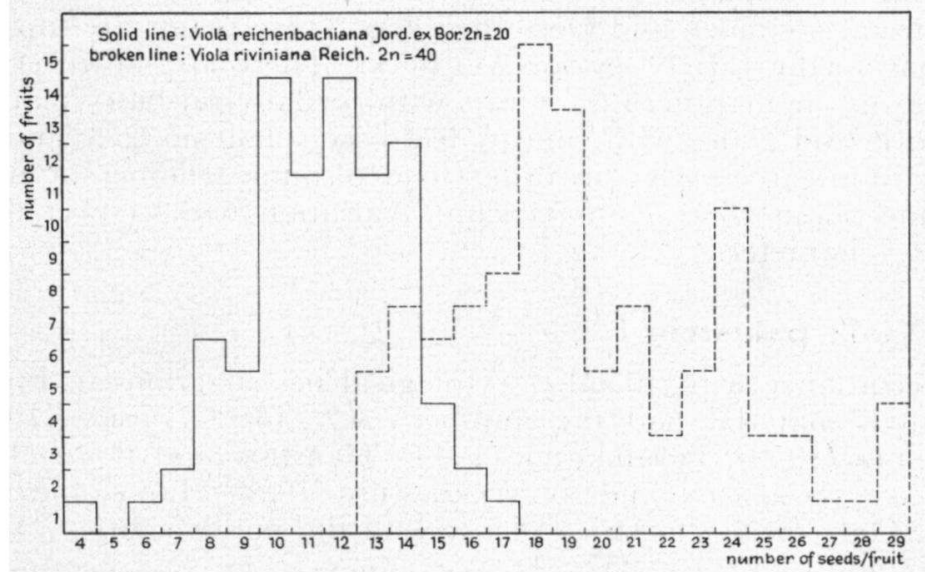

Fig. 5. The difference in the number of seeds per fruit between Viola riviniana Rchb. and Viola reichenbachiana Jord. ex Bor.

The germination of the seeds presented some difficulties. The seeds only germinated outside the greenhouse after a period of frost. This is in accordance with an observation by GeRSHOY, (1928).

Hybrids between the species were not met with in the Netherlands. On the island of Voorne a hybrid between $V$. riviniana and $V$. canina was found. This plant resembled the $V$. riviniana parent, but had much 
larger vegetative and floral parts. The chromosome number of the hybrid turned out to be $2 n=40$. No seeds were formed during 3 years of cultivation, all cleistogamous flowers withered within a few days. The pollengrains were quite abnormal, mostly shrivelled, and many dwarf pollengrains were formed.

e) Viola rupestris F. Schmidt var. arenaria (D.C.) W. Beck.

The chromosome number $2 n=20$ agrees with all cytological observations mentioned in the literature: Clausen (1929, 1931a), Gershoy (1934), SGhöfer (1954), Schmidt (1961).

\section{f) Viola canina L.}

In accordance with several authors: BruUn (1932), Fothergill (1944) Gershoy (1934), Löve and Löve (1956), Moore (1957), Moore and Harvey (1961), Schöfer (1954), Schmidt (1961), but in contrast to J. Clausen $(1931 \mathrm{~b}, 1932)$, for this species only the number $2 n=40$ was found in the Netherlands.

Contrary to the observations of J. Clausen in Denmark, in our material no abnormal pollengrains were observed. Morphologically the material from Rosmalen was somewhat different from the plants collected in other parts of the country. These plants were tall and slender, but after 4 years of cultivation under uniform conditions they did not differ from other plants.

In some dune plants the leaf-base was cuneate, not cordate, as in plants from Rosmalen and Oosterhesselen. These plants are supposed to belong to the variety dunensis $W$. Beckr. There are, however, also plants from the margin of the dunes with cordate leaf-base (plant no. 81) and inland plants with cuneate leaf-base (plant no. 214). Further investigations are needed in order to determine whether or not in our dune plants there exists ecoclinic variation with respect to the leaf-base character.

\section{g) Viola palustris L.}

In accordance with all other cytological investigations in Europe, the Dutch material had the number 2n = 48: Clausen (1931a), Fernandes (1950), Fothergill (1944), Gershoy and Bold (1934), Jörgensen, Sörensen and WestergaARd (1958), Löve and Löve (1956). Only in North Africa plants with the number $2 n=24$ have been found (QuezeL, 1957).

\section{h) Viola tricolor L.}

The chromosomes of $V$. tricolor L., $V$. arvensis Murr., and $V$. calaminaria Lej. (all belonging to the section Melanium) are larger than those of the species dealt with in this paper, which belong to the section Nominium.

The inland as well as the dune form has the chromosome number $2 n=26$. This is in accordance with all other cytological investigations: 

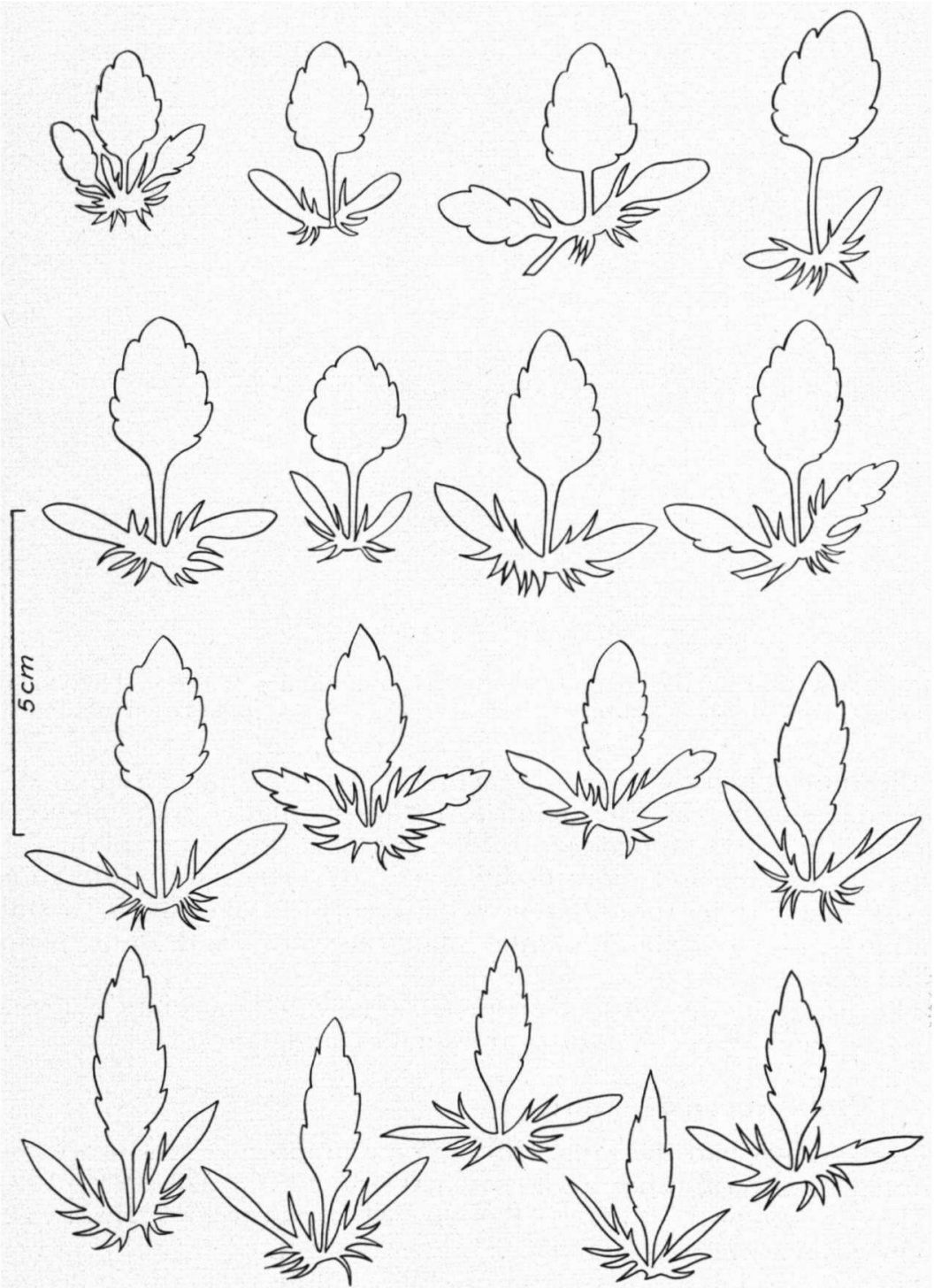

Fig. 6. Variation in the shape of the leaves and stipules of the middle cauline region of Viola tricolor L. subspec. tricolor (population Hollandse Rading).

Clausen (1921, 1926, 1927, 1931a), Fothergill (1938, 1941, 1944), Gershoy (1934).

Morphologically the two subspecies are clear-cut. During 4 years of cultivation under uniform conditions the annual inland form (subspec. tricolor) kept its ascending habit, whereas the perennial dune plants (subspec. curtisii) remained prostrate. Besides, the length of the spur 


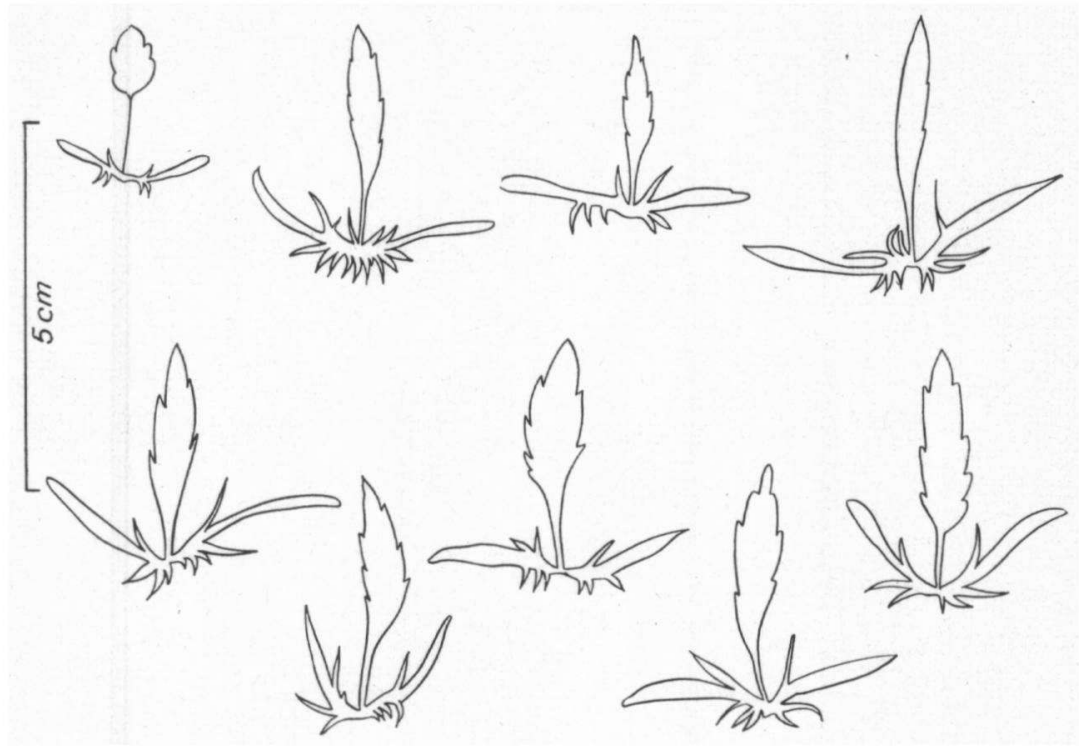

Fig. 7. Variation in the shape of the leaves and stipules of the middle cauline region of Viola tricolor L. subspec. curtisii (Forst.) Syme (population Ouddorp).

of the dune plants was (and remained) twice as long as the calyx appendages, whereas the inland form has a smaller spur, about as long as the calyx appendages. The leaves of the dune plants are generally smaller and more fleshy, even after 4 years of cultivation. Figs. 6 and 7 show the differences between the leaves of the middle cauline region of inland plants (plant no. 116) and dune plants (plant no. 128).

The leaves of the subspecies tricolor are ovate-lanceolate, whereas those of the subspecies curtisii are smaller and lanceolate.

\section{i) Viola arvensis Murr.}

Our samples had the same chromosome number as was previously counted by several other authors: CLAUSEN (1921, 1922, 1926, 1927, 1931a), Fothergill (1944), Kondo, Matsunami and Hagrwara (1956), Löve and Löve (1956).

The leaves and stipules of the middle cauline region of collection number 216 are shown in Fig. 8, in order to permit a comparison with the leaves of $V$. tricolor. The stipules are sometimes of the same shape as the foliage leaves (fig. 8, no. 2); the leaves are often much larger than those of Viola tricolor.

\section{j) Viola calaminaria Lej.}

11 plants were collected near La Calamine (Belgium) on rubble of a zinc mine in a typical Violetum calaminariae. Six plants permitted chromosome counts: $2 n=52$. 

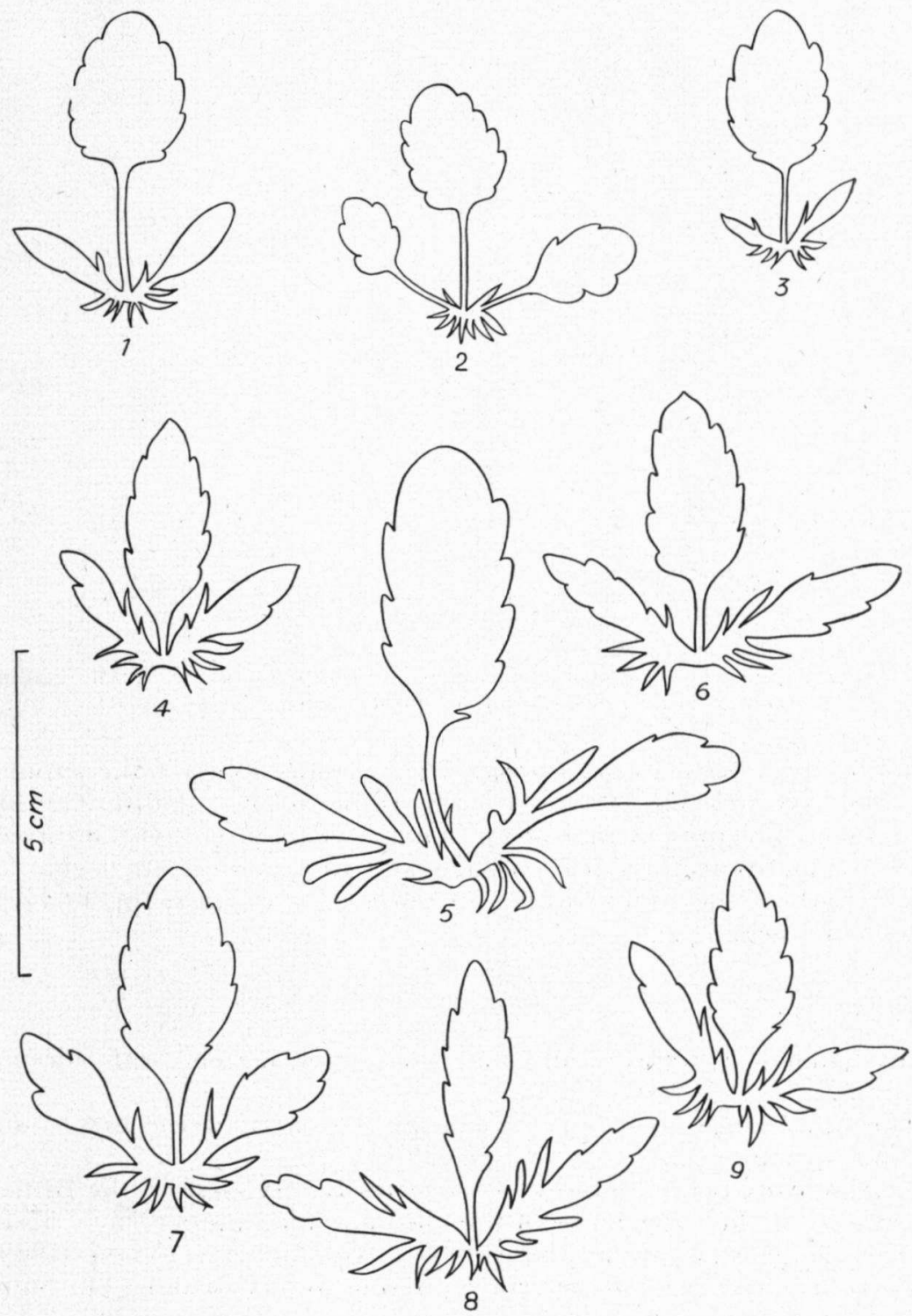

Fig. 8. Variation in the shape of the leaves and stipules of the middle cauline region of Viola arvensis Murr. (population Hilversum).

Viola calaminaria has many morphological characters in common with the Viola tricolor-complex. For example, the length of the spur agrees with that of $V$. tricolor. L. subspec. curtisii (Forst.) Syme. Sometimes the stipules are palmatipartite (fig. 9 no. 1) which is characteristic for $V$. lutea, sometimes they are pinnatipartite, which 


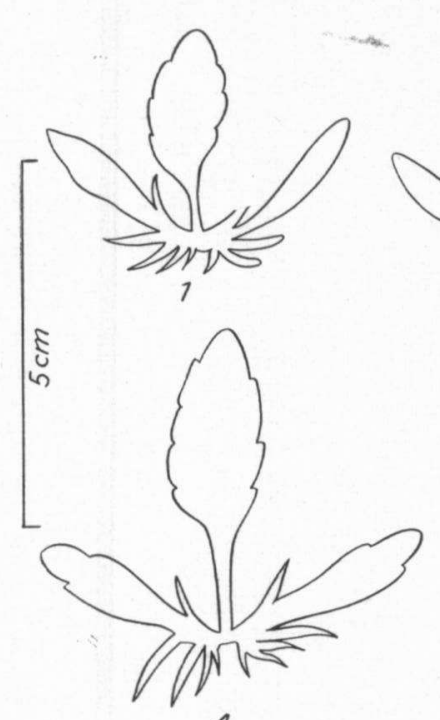

4
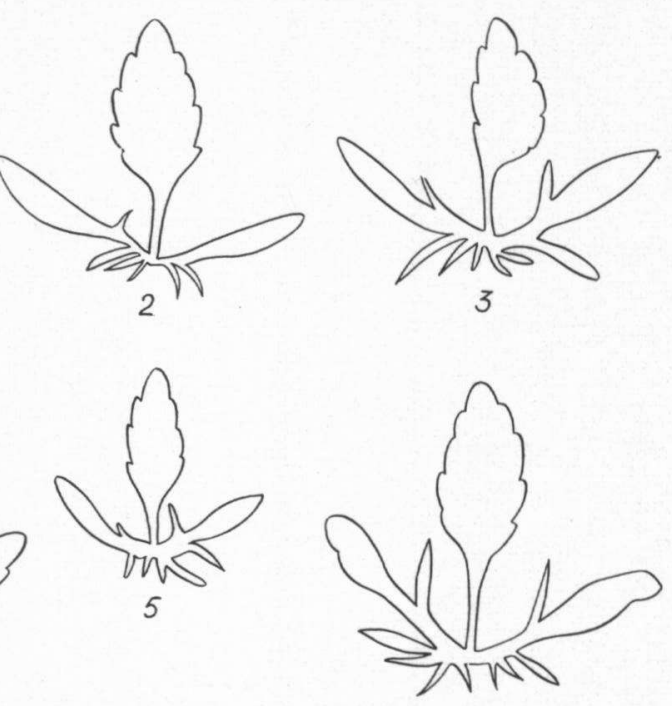

6

Fig. 9. Variation in the shape of the leaves and stipules of the middle cauline region of Viola calaminaria Lej. (population la Calamine).

is said to be typical for $V$. tricolor. The terminal lobes of the stipules may be crenate (Fig. 9 no. 4), according to Fothergill (1944) a character not present in $V$. lutea. After 4 years of cultivation under uniform conditions these leaf characters as well as some other characters (length of the spur, width and shape of the calyx appendages) remained unchanged.

\section{Conclusions}

In cytological respect our material agrees largely with foreign material.

The number $2 \mathrm{n}=52$ for $V$. calaminaria represents the first count for this species.

Cytologically our material of $V$. riviniana is very close to the British material. For the occurrence of the chromosome number $2 n=35$ in V. riviniana no explanation can be offered. Although VALENTINE (1949) reports this number for material originating from Croxdale, Durham, he does not discuss these plants further. The report is perhaps due to a printer's error.

Contrary to Schmidt, Schöfer and Valentine, no hybrids between $V$. riviniana and $V$. reichenbachiana could be found. Plants with $2 n=30$ were not met with, even in mixed populations. The plants with the number $2 n=40$ showed all very clearly the typical characters of $V$. riviniana as described by Valentine and could, therefore, not be regarded as hybrids. Moreover, all the plants examined had a good seed production, which does not occur in artificially produced hybrids. 
On the other hand, in South Germany the seed production of the plants regarded as hybrids with the numbers $2 n=30$ and $2 n=40$ was not abnormal. It is to be regretted that Schöfer failed to give detailed descriptions of the putative hybrids. In the author's opinion there are two possibilities concerning these plants:

1) the material from S. Germany is genetically different from the English material;

2) the plants with the number $2 n=40$ are not of hybrid origin.

The absence of supernumerary chromosomes in the material from S. Germany corroborates the first assumption. The production of normal seeds is in better agreeance with the second. It would be highly desirable to have detailed descriptions of some of the hybrid populations in S. Germany, in order to facilitate a comparison with the material from England and the Netherlands.

The Dutch material of $V$. riviniana is morphologically variable. It was, however, not possible to divide the plants from 11 different populations into the subspecies minor and nemorosa, even after 4 years of cultivation under uniform garden conditions. Some plants from woods had 3 nemorosa and 5 minor characters, while other plants from the open dune landscape showed 4 nemorosa and 4 minor characters. There was no relation between the environment and morphological characters, nor did any plant possess a combination of the characters regarded as typical for the subspecies nemorosa and minor by Valentine. Therefore it seems impossible to divide the Dutch material into these two subspecies. VALENTiNe (1941) suggests that plants of the nemorosa type may have more than 40 chromosomes, whereas the plants of the minor type always have 40 chromosomes. The Dutch plants with supernumerary chromosomes however, showed several minor characters.

Heimans's opinion that $V$. calaminaria should not be referred to $V$. lutea but to the $V$. tricolor-complex could be confirmed. KLoos (1924) was already of the opinion that $V$. calaminaria is related to $V$. tricolor. Heimans concludes on several grounds that $V$. calaminaria could be derived from $V$. tricolor L. var. alpestris Ging. apud DC. $[=V$. alpestris (DC.) Wittr.]

The subspecies curtisii of $V$. tricolor resembles $V$. calaminaria in many respects. The number of chromosomes and the ecological requirements are in favour of treating $V$. calaminaria as a separate species.

Contrary to $V$. riviniana no intraspecific cytological variation could be observed in V. canina in the Netherlands. Only in Denmark fertile plants (some of which are hybrids) with more than 40 chromosomes are present.

\section{ACKNOWLEDGEMENTS}

These investigations were carried out in the Institute for Systematic Botany, Lange Nieuwstraat 106, Utrecht (director Prof. Dr. J. Lanjouw) and were partly made possible by a grant of the Dutch Organisation for Pure Scientific Research (Z.W.O.). The author is much indebted to Mr. P. A. Florschütz and Mr. E. A. Mennega for their assistance with the collecting of the material, to Dr. K. U. Kramer. for his help with the correction of the English text, to Mr. W. Fromme for his assistance with the cultivation of the plants, and to Mr. T. Schipper for his help with the drawings. 


\section{REFERENCES}

BRUUr, H. G. 1932. A theory on the cytologically irregular species Viola canina. Hereditas 16: 63-72.

Cuausen, J. 1921. Studies on the collective species Viola tricolor L. Bot. Tidsskr. 37: 204-221.

1922. Studies on the collective species Viola tricolor L. (II). Bot. Tidsskr. 37: 363-461.

1926. Genetical and cytological investigations on Viola tricolor L. and V. arvensis Murr. Hereditas 8: 1-156.

1927. Chromosome number and the relationship of species in the genus Viola. Ann. of Bot. 41 : 677-714.

1929. Chromosome number and relationship of some North American species of Viola. Ann. of Bot. 43: 741-764.

- 1931a. Danmarks Viol-Arter. Bot. Tidsskrift 11: 317-335. 15: 67-88.

1931c. Cytogenetic and taxonomic investigations on Melanium violets. Hereditas 15: 219-308.

- 1932. Remarks upon H. G. Bruun's paper on Viola canina L. Hereditas 17: $67-70$.

Deray, C. 1948. Recherches sur la structure des noyaux quiescents chez les phanérogames. Rev. de Cytol. et de Biol. Vég. 10: 103-229.

Fernandes, A. 1950. Sobre a cariologia de algumas plantas da Serra do Gerês. Agron. Lusit. 12: 551-600.

FotherginL, P. G. 1938. Studies in Viola. I. The cytology of a naturally occurring population of hybrids between V. tricolor and V. lutea Huds. Genetica 20: $159-186$.

1941. Studies in Viola III. An account of the inheritance of certain characters in the progeny of plants of a wild population of Viola hybrids. New Phytol. 40: 139-151.

1944. Studies in Viola IV. The somatic cytology and taxonomy of our British species of the genus Viola. New Phytol. 43: 23-35.

Gershoy, A. 1928. Studies in North American Violets. I. General considerations. Vermont Agric. Exp. Stat. Bull. 279: 1-18.

1934. Studies in North American Violets. III. Chromosome numbers and species characters. Univ. Vermont Agric. Exp. Stat. Bull. 367: 1-92. and H. C. Bord. 1934. Studies in North American Violets IV. Univ. Vermont Agric. Exp. Stat. 378: 1-35.

Gorczynski, A. 1929. Recherches histo-cytologiques sur les fleurs cleistogames chez Lamium amplexicaule, Oxalis acetosella et Viola odorata. Acta Soc. Bot. Polon. 6: 248-295.

Griesinger, R. 1937. Ueber hypo- und hyperdiploide Formen von Petunia, Hyoscyamus, Lamium und einige andere Chromosomenzählungen. Ber. Deutsch. Bot. Ges. 55: 556-571.

Heimans, J. 1936. De herkomst van de zink-flora aan de Geul. Nederl. Kruidk. Arch. 46: 878-893.

1960. Taxonomic, phytogeografical and ecological problems round Viola calaminaria, the zinc violet. Publ. Natuurhist. Genootsch. Limburg 12: $55-71$.

HeIlborn, O. 1926. Bidrag till Violaceernas cytologi. Sv. Bot. Tidskr. 20 : 414-419.

Jörgensen, G. A., Th. Sörensen and M. WestergaArd. 1958. The flowering plants of Greenland. A taxonomical and cytological survey. Dansk Vid. Selsk. Biol. Skr. 9, 4: 1-172.

Kıoos, A. W. 1924. Het geslacht Viola in Nederland. Nederlands Kruidk. Arch. 34: 138-208.

Kondo, N., M. Matsunam, and T. Hagiwara. 1956. Chromosome number of pansy and some cultivated Viola. Jap. J. Genet. 31: 302.

LARSEN, K. 1954. Chromosome numbers of some European flowering plants. Bot. Tidsskr. 50: 163-174. 
Löve, A. 1950. Some innovations and nomenclatural suggestions in the Icelandic flora.

Bot. Not. (1950): 24-60.

Löve, A. and D. LövE. 1956. Conspectus of the Icelandic Flora. Acta Horti Gotoburgensis 20 (4): 65-291.

MADGE, M. A. 1929. Spermatogenesis and fertilization in the cleistogamous flower of Viola odorata L. var. praecox Greg. Ann. Bot. 43: 545-577.

Manch, D. 1937. Meiosis in an F1 Viola hybrid and its recipocal. Am. Journ. Bot. 24: 678-683.

Mryajr, Y. 1929. Studien über die Zahlenverhältnisse der Chromosomen bei der Gattung Viola. Cytologia 1: 28-58.

MrYaJ1, Y. 1930. Betrachtungen über die Chromosomenzahlen von Violen, Violaceen und verwandten Familien. Planta 11: 631-649.

Moore, D. M. 1957. The status of Viola lactea. in: Lousley, J. E. (ed). Progress in the study of the British flora. 1957: 97-102.

Moore, D. M. and M. J. HARVEY. 1961. Cytogenetic relationships of Viola lactea $\mathrm{Sm}$. and other West European arosulate violets. New Phytol. 60: 85-94.

Quezel, P. 1957. Peuplement végétal des hautes montagnes de l'Afrique du Nord. Encycl. Biogeogr. et Ecol. 10: 1-445.

SchöFER, G. 1954. Untersuchungen über die Polymorphie einheimischer Veilchen. Planta 43: 537-565.

Schmidт, A. 1961. Zytotaxonomische Untersuchungen an europäischen ViolaArten der Sektion Nominium. Oesterr. Bot. Zeitschr, 108: 20-88.

Théron, A. 1939. Recherches morphologiques et cytologiques sur les fleurs de Viola odorata. Rev. Cyt. Cytophysiol. Vég. 4: 101-118.

VAlentine, D. H. 1941. Variation in Viola riviniana Rchb. New Phytol. 40: 189-209.

1949. Vegetative and cytological variation in Viola riviniana Rchb. In Willmott, Brit. Flow. Plants and Modern Syst. Methods. (B.S.B.I. Conference 1948): 48-53.

. 1950. The experimental taxonomy of two species of Viola. New Phytol. 49: 193-212.

1956. Variation and polymorphism in Viola. Proc. Royal Soc. 145: 315-319.

-_ 1958. Cytotaxonomy of the Rostrate Violets. Proc. Linn. Soc. London 169: $132-134$.

WEsT, J. 1930. Cleistogamy in Viola riviniana with especial reference to its cytological aspects. Ann. Bot. 44: 87-109. 